\title{
Effect of concrete slats, three mat types and out-wintering pads on performance and welfare of finishing beef steers
}

\author{
Bernadette Earley ${ }^{1 *}$, John D. McNamara², Stephen J. Jerrams² and Edward G. O'Riordan ${ }^{3}$
}

\begin{abstract}
Background: The objective was to investigate the effect of placing mats on concrete slatted floors on performance, behaviour, hoof condition, dirt scores, physiological and immunological variables of beef steers, and to compare responses with animals on out-wintering pads. Continental crossbred beef steers $[n=360$; mean $( \pm S D)$ initial live weight $539 \mathrm{~kg}$ (42.2)] were blocked by breed and live weight and randomly assigned to one of five treatments; (1) Concrete slats alone, (2) Mat 1 (Natural Rubber structure) (Durapak Rubber Products), (3) Mat 2 (Natural rubber structure) (EasyFix), (4) Mat 3 (modified ethylene vinyl acetate (EVA) foam structure) and (5) Out-wintering pads (OWP's).

Results: Animals on the OWPs had a greater $(P<0.05)$ live weight gain $(P<0.05)$ compared with the slat and Mat 2 treatments: results for Mat 1 and Mat 3 were the same $(P>0.05)$ as the other treatments. Animals on the OWPs had reduced lying percentage time compared with all the other treatments. Dry matter (DM) intake was greater for animals on the OWPs compared with all the other treatments. Carcass weight, kill out proportion, carcass fat score, carcass composition score, FCR and physiological responses were similar $(P>0.05)$ among treatments. No incidence of laminitis was observed among treatments. The number of hoof lesions was greater on all mat types $(P<0.05)$ compared with concrete slats and OWP treatments. Dirt scores were greater $(P<0.05)$ for animals on OWPs when measured on days 42, 84, 105, 126 and 150 compared with animals on slats.

Conclusions: Under the conditions adopted for the present study, there was no evidence to suggest that animals housed on bare concrete slats were disadvantaged in respect of animal welfare compared with animals housed on other floor types. It is concluded that the welfare of steers was not adversely affected by slats compared with different mat types or OWPS.
\end{abstract}

Keywords: Housing, Animal welfare, Concrete slat, Rubber mat

\section{Background}

There is a shortage of published research on the effect of placing mats on concrete slats in facilities for winter finishing beef cattle. Most previous housing studies reported significant behavioural alterations concerning the welfare of cattle accommodated on fully slatted concrete floors [1-9]. Elmore et al. [1] reported that the addition of slatted rubber mats to concrete pens improved locomotion,

\footnotetext{
*Correspondence: bernadette.earley@teagasc.ie

${ }^{1}$ Animal and Bioscience Research Department, Animal \& Grassland Research and Innovation Centre, Teagasc, Grange, Dunsany, Co. Meath C15 PW93, Ireland

Full list of author information is available at the end of the article
}

leg and joint health, and alterations in behaviour that are indicative of increased traction and reduced discomfort in finishing beef steers. Other studies have measured the growth of finishing cattle in response to a range of space allowances [10-13]. Biological performance is an indicator of animal well-being and previous studies have demonstrated that stress due to reduced space allowance can negatively affect animal performance [13-16]. Schlichting et al. and Schlichting and Smidt $[15,16]$ reported that the abrasive effect of the concrete slatted floor led to reduced slipping of hooves on contact. A study by Murphy et al. [17] measured the in vitro abrasion on a wear-testing instrument of hoof horn samples of cattle 
in relation to breed and housing. The hoof horn of Friesian cattle was softer if they had been housed on concrete slats rather than on straw, but there was no such effect in Hereford cattle. Interest in out-wintering pads (OWPs) as a low cost alternative to indoor housing is another system that has been studied [18]. The OWP's consist of a woodchip lying area constructed over a drainage system, which may or may not be sheltered. Animals have access to feed from a self-feeder at the feed-face of the OWP. The OWP system has been shown, under experimental conditions, to meet environmental guidelines as well as being capable of supporting satisfactory animal performance, health and welfare [18].

The hypothesis of the study was that the provision of a Mat flooring or an out-wintering pad (OWP) would offer protection to the animals' feet, particularly over a 150-day winter period, which would in turn improve hoof health. Furthermore, it was hypothesised that finishing cattle on the mats or OWPs would have enhanced performance compared with concrete slats owing to more comfortable underfoot conditions that would in turn lead to improvements in animal welfare. The objective was to investigate the effect of placing mats on concrete slatted floors on performance, hoof condition and body cleanliness of finishing beef steers, and to compare responses with animals on out-wintering pads. Accordingly, this study examined the behavioural, physiological and immunological responses of the steers by assessing the consequences of the floor type on the welfare of finishing beef cattle that were offered a total mixed ration (TMR) diet.

\section{Methods}

\section{Environmental conditions}

This study was conducted at Teagasc Grange, located in Co. Meath, Ireland (latitude 53.52187, longitude-6.65247). The mean daily air temperature in the housing facility (from November to May) and the ambient environment was continuously recorded using Testo 175 data loggers (Radionics, Dublin, Ireland).

\section{Animals, experimental design and diet}

Continental crossbred beef steers $[\mathrm{n}=360$; mean $( \pm \mathrm{SD})$ initial live-weight $539 \mathrm{~kg}$ (42.2)] were blocked by breed and live-weight and randomly assigned to one of five treatments; (1) Concrete slats alone, (2) Mat 1 (Natural Rubber structure) (Durapak Rubber Products, Cork, Ireland), (3) Mat 2 (Natural rubber structure) (EasyFix, Galway, Ireland), (4) Mat 3 [modified ethylene vinyl acetate (EVA) foam structure (Mayo, Ireland)] and (5) Outwintering pads (OWPs) (constructed in 2006). Animals assigned to treatments 1-4 were accommodated in a roofed building with concrete slatted floors. The concrete slats (5 gang/pen) in the pens were supplied by Banagher Concrete Ltd., Offaly, Ireland. Each gang slat had the following dimensions; void length $945 \mathrm{~mm} \times 3 \mathrm{~mm}$; void space $35 \mathrm{~mm}$; slat length $3.5 \mathrm{~m}$; slat rib width $170 \mathrm{~mm}$; slat width $1.18 \mathrm{~m}$. The mats were supplied and fitted to the concrete slats in the cattle pens by the respective suppliers. There were eight pens per treatment, with nine steers per pen at a mean space allowance of $2.73 \mathrm{~m}^{2} /$ head, whereas animals accommodated outdoors on the OWPs had a space allowance of $12 \mathrm{~m}^{2} /$ head. The shed was dimly lit using infra-red lighting to allow visualisation during the behavioural studies.

\section{Animal diet}

All animals were fed a total mixed ration (TMR) of silage and rolled barley on a 50:50 dry matter (DM) basis. Typically $2000 \mathrm{~kg}$ of silage and $500 \mathrm{~kg}$ rolled barley was mixed in a 12 cubic meter Abbey Vertical Mixer (VF 12) fitted with a Digistar weighing system. Feed was weighed into each group every day at 9:00 throughout the study and refusals were measured twice weekly. The steers had free access to water drinkers in their pens. Each pen was fitted with a single $2 \mathrm{l}$ nose fill water bowl which was positioned $55 \mathrm{~cm}$ above the floor of the pen. The TMR samples offered were submitted to Grange Labs at Teagasc for chemical analysis [dry matter digestibility (DMD), crude protein $(\mathrm{CP})$, ash, neutral detergent fibre (NDF)] and $\mathrm{pH}$ analyses [19]. Animals were vaccinated with a Covexin 8 (Merck, Animal Health, MSD Animal Health, Dublin, Ireland) and a Bovilis-Bovipast RSP (Merck, Animal Health, MSD Animal Health, Dublin, Ireland) injections 3 weeks prior to commencement of the study.

\section{Health}

The general health status of the steers was recorded by a trained staff member. A complete record of any clinical symptoms by infection or injury and their veterinary treatment was maintained.

\section{Hoof condition}

The general condition of the four hooves of each animal was recorded prior to (day 0 ) and at the end of the study (i.e., on retrieval of the hooves post-slaughter of the animals). A single observer, who was experienced in hoof examination assessed the four hooves of each animal on both occasions and preliminary scoring was carried out to verify repeatability of results. The hooves were trimmed on day 0 and again on the retrieval of the hooves post-slaughter, to allow visualization. Both claws per each of the four hooves were examined by the same trained observer for the presence of lesions using the method of Greenough and Vermunt [20]. The dorsal area was examined for equal and unequal size and the plantar 
area for heel erosion, under run sole, digital dermatitis, inter-digital dermatitis and white line damage. The total number of lesions was averaged over all four hooves and the number each animal had obtained during the study was determined. Animals were observed for any signs of lameness every 3 weeks to coincide with animal live weight recordings. All animals were assessed by the same trained person for abnormal gait and back posture while walking and standing using the method of Sprecher et al. [21] on a scale of 1 (normal) to 5 (abnormally lame).

\section{Animal cleanliness scoring}

All animals were dirt scored on day 0 before assignment to treatment and at 21 day intervals (day 0, 21, 42, 63, $84,105,126$ and 150) throughout the study. Dirt scoring was carried out by the same person on each occasion and was carried out blind to treatment. The body dirt scoring system used by Earley et al. [22], which was adapted from Scott and Kelly [23] was applied. Using this system, the entire left side of each animal was diagrammatically divided into 16 body segments and each segment was assigned a score between 1 (very clean) and 5 (very dirty) levels of intensity. Each animal was then given an overall dirt score between 16 and 80, which was equal to the sum of the scores for each of the 16 body segments [22].

\section{Behaviour}

An individual Eneo CCTV camera was placed over each pen and the behavioural data were recorded. Behavioural observations were conducted over six 3-week intervals, continuously for $72 \mathrm{~h}$ duration. Animals were identified by their natural body markings. During the period of darkness, the shed housing the animals was dimly lit using infra-red lights to allow observation of the animals on the CCTV cameras. The cameras were connected to a video tape recorder (Panasonic AG6040) via a multivision system (Panasonic WJ-FS109, monochrome duplex multiplexer, Lynx, Dunsany, Co. Meath, Ireland) which allowed pictures from all cameras to be viewed on one screen at a time. The pictures from all the cameras were marked with individual pen number, time and date settings. The behavioural analysis was performed by a trained staff member. Steers were observed by instantaneous scan sampling of the CCTV recordings. The interval between scans was $10 \mathrm{~min}$. This interval was chosen based on previous recording of animal behaviours [22, 24]. Each steer was observed for behavioural activity and body contact. Counts of lying, standing, eating and drinking, mounting, head-butting, licking and grooming were recorded. In the behavioural activity category, steers were observed for the following: lying down: head supported by the neck, head not supported by the neck (chin on the floor, on the body or on another steer); standing: with or without moving; eating (head in the trough); drinking; head to head contact except while eating; head contact with the body of another steer; and mounting. In the contact category the criteria were: no body contact with other steers and contact with one, two or three steers; grooming refers to self-grooming and allogrooming constitutes licking another animal.

\section{Average daily live weight and carcass characteristics}

Live weights were measured on day- 1 and again on day 0 before assignment to treatment, at 21-day intervals (day $0,21,42,63,84,105,126$ and 150) throughout the study and average daily gain (ADG) determined. Animals were slaughtered from day 150 of the experiment onwards. Cold carcass weights were recorded, with carcass conformation and fat scores graded using a video imaging analysis carcass classification system (VBS 2000, E + P, Oranienberg, Germany) based on the EU Beef Carcass Classification Scheme according to the EU beef carcass classification scheme (EC, 2006) [25]. Feed conversion ratio (FCR) was expressed as kilograms of $\mathrm{DMI} /$ pen/day divided by kilograms of live weight gain/pen/day.

\section{Physiological, haematological and immunological variables}

Animals were blood sampled via jugular venipuncture on days 0 and 150 . For the blood sampling procedure, the animals were moved to a holding pen with a squeeze chute facility and were blood sampled with minimal restraint. Blood sampling was carried out by the same experienced operator on each occasion and the time taken to collect the blood samples was less than $60 \mathrm{~s} /$ animal.

\section{Haematological measurements}

Blood samples were collected into $(1 \times 6 \mathrm{ml}) \mathrm{K}_{3}$ ethylenediaminetetraacetic acid (K $\mathrm{K}_{3}$ EDTA) tube (Vacuette, Cruinn Diagnostics, Ireland) for haematological cell distributions and haemoglobin content determined using an automated analyser (Celltac MEK-6108 K; NihonKohdon, Tokyo, Japan) and reagents supplied by Celltac (Alpha Technologies, Dublin, Ireland).

\section{Blood metabolites, acute phase proteins and immune measurements}

Heparinized blood samples were collected by jugular venipuncture and the plasma was separated by centrifugation at $1600 \times g$ at $8^{\circ} \mathrm{C}$ for $15 \mathrm{~min}$ (except for interferon (IFN)- $\gamma$ at $300 \times g$; at $8{ }^{\circ} \mathrm{C}$ for $15 \mathrm{~min}$ ) and subsequently stored at $-20{ }^{\circ} \mathrm{C}$ until assayed for subsequent analysis of metabolic variables associated with mobilization of body energy reserves, dehydration and muscle injury [albumin, total protein, creatine kinase (CK), glucose, 
non-esterified fatty acid (NEFA), ßeta-hydroxy butyrate $(\beta \mathrm{HB})]$, inflammatory biomarkers (the acute phase proteins (fibrinogen, haptoglobin) and a measure of cell mediated immunity interferon-(IFN) $\gamma$ production [26]).

\begin{abstract}
Albumin
The concentration of albumin was determined on an automatic clinical analyser (Olympus AU400 Clinical Analyser, Tokyo, Japan) using the reagents supplied by Olympus (catalogue number OSR6102). The composition of the reagents (at final concentration) required for this test were: succinate buffer $(\mathrm{pH} 4.2)(100 \mathrm{mmol} / \mathrm{l})$ and bromocresol green $(0.2 \mathrm{mmol} / \mathrm{l})$ and following gentle inversion the reagents were ready to use directly from the kit.
\end{abstract}

\section{Total protein}

The concentration of total protein in plasma was determined on an automatic clinical analyser (Olympus AU400 Clinical Analyser, Tokyo, Japan) using the reagents supplied by Olympus (catalogue number OSR6132) (Olympus UK Ltd., Voice House, Watford, Hertfordshire, WD24 4JL, UK). The composition of the reagents (at final concentration) required for this test were; sodium hydroxide $(200 \mathrm{mmol} / \mathrm{l})$, potassium sodium tartrate (32 $\mathrm{mmol} / \mathrm{l})$, copper sulphate $(18.8 \mathrm{mmol} / \mathrm{l})$ and potassium iodide $(30 \mathrm{mmol} / \mathrm{l})$ and following gentle inversion the reagents were ready to use directly from the kit.

\section{Creatine kinase (CK)}

The activity of CK was determined on an automatic clinical analyser (Olympus AU400 Clinical Analyser, Tokyo, Japan) using the reagents supplied by Olympus (catalogue number OSR6179). The composition of the reagents (at final concentrations of reactive ingredients) required for this test were: imidazole $(\mathrm{pH}$ 6.5) $(100 \mathrm{mmol} / \mathrm{l})$, NADP ( $2 \mathrm{mmol} / \mathrm{l}), \operatorname{ADP}(2 \mathrm{mmol} / \mathrm{l}), \operatorname{AMP}(5 \mathrm{mmol} / \mathrm{l})$, EDTA (2 $\mathrm{mmol} / \mathrm{l})$, glucose $(20 \mathrm{mmol} / \mathrm{l})$, creatine phosphate (30 $\mathrm{mmol} / \mathrm{l})$, n-acetlycysteine $(0.2 \mathrm{mmol} / \mathrm{l})$, activator (26 mmol/l), $\mathrm{Mg}^{2+}(10 \mathrm{mmol} / \mathrm{l})$, diadenosine pentaphosphate $(0.01 \mathrm{mmol} / \mathrm{l})$, hexokinase $(>4 \mathrm{kU} / \mathrm{l})$ and glucose6-phosphate dehydrogenase $(>2.8 \mathrm{kU} / \mathrm{l})$. Prior to the placement of the reagents on board the instrument, the entire kit contents of R1-2 ( $4 \mathrm{ml})$ were transferred to the entire kit contents of R1-1 (22 ml) and mixed by gentle inversion. The second reagent bottle (R2) $(6 \mathrm{ml})$ was ready to use from the kit and was placed directly on the instrument.

\section{Glucose}

The concentration of glucose was determined on an automatic clinical analyser (Olympus AU400 Clinical Analyser, Tokyo, Japan) using the reagents supplied by Olympus (catalogue number OSR6121). The composition of the reagents (at final concentration of reactive ingredients) required for this test were: piperazine$N, N$-bis (ethanesulfonic acid (PIPES) buffer $(\mathrm{pH} 7.6)$ $(24 \mathrm{mmol} / \mathrm{l}))$, ATP $(\geq 2 \mathrm{mmol} / \mathrm{l}), \mathrm{NAD}^{+}(\geq 1.32 \mathrm{mmol} / \mathrm{l})$, $\mathrm{Mg}^{2+}(2.37 \mathrm{mmol} / \mathrm{l})$, hexokinase $(\geq 0.59 \mathrm{mmol} / \mathrm{l})$, G6P$\mathrm{DH}(\geq 0.59 \mathrm{mmol} / \mathrm{l})$ and required no preparation prior to placement on the instrument.

\section{Non-esterified fatty acids}

The concentration of non-esterified fatty acids (NEFA) was determined on an automatic clinical analyser (Olympus AU400 Clinical Analyser, Tokyo, Japan) using the reagents supplied by Randox Laboratories (catalogue number FA115) (Randox Labs ltd., Ardmore, Diamond Rd., Crumlin BT29 4QY, Co. Antrim, Ireland). The kit comprised of five reagents. The buffer (R1a) and enzyme diluent (R2a) were ready to use from the kit. The enzyme/coenzymes (R1b) were reconstituted with $10 \mathrm{ml}$ of buffer (R1a) and mixed by gently swirling. Maleimide (R2b) was reconstituted with enzyme diluent (R2a) and was inverted several times to ensure that maleimide was completely dissolved. This was then used immediately to reconstitute enzyme reagent (R2c) which was protected from light and placed on board the instrument for analysis. All reagents were kept at $4{ }^{\circ} \mathrm{C}$ prior to and after preparation.

\section{$\beta$-Hydroxy butyrate ( $\beta H B$ )}

The concentration of $\beta \mathrm{HB}$ was determined on an automatic clinical analyser (Olympus AU400 Clinical Analyser, Tokyo, Japan) using the reagents supplied by Randox Laboratories (catalogue number RB 1007). The kit comprised of five reagents: R1a [Buffer (Tris buffer (pH 8.5) $100 \mathrm{mmol} / \mathrm{l})$, EDTA ( $2 \mathrm{mmol} / \mathrm{l})$, Oxalic acid $(20 \mathrm{mmol} / \mathrm{l})]$ and R1b (Enzyme/Coenzyme $\mathrm{NAD}+2.5 \mathrm{U} / \mathrm{ml}$; 3-hydroxybutyrate dehydrogenase $0.12 \mathrm{U} / \mathrm{ml})$ ). The reagents were stored at $4{ }^{\circ} \mathrm{C}$ prior to and after preparation.

\section{Acute phase protein response (fibrinogen and haptoglobin)}

Blood collected into vacutainer tubes containing lithium heparin and sodium citrate was used to determine the plasma concentration of haptoglobin and fibrinogen, respectively. Plasma was harvested following centrifugation at $1600 \times g$ at $4{ }^{\circ} \mathrm{C}$ for $15 \mathrm{~min}$ and stored at $-80{ }^{\circ} \mathrm{C}$ until assayed. Plasma concentration of haptoglobin was measured using an automatic analyser (spACE, Alfa Wassermann, Inc., West Caldwell, NJ, USA) and commercial assay kit (Tridelta Development Ltd., Wicklow, Ireland) according to the manufacturer's procedure as described by Eckersall et al. [27]. Plasma concentration of fibrinogen was measured using an automatic analyser (spACE, Alfa Wassermann, Inc., West Caldwell, NJ, USA) using a method described by Becker et al. [28]. 


\section{Immune variable; interferon- $\gamma$ (IFN- $-\gamma)$}

Blood samples for IFN- $\gamma$ determination were collected by jugular venipuncture into aseptic vacutainer tubes containing lithium heparin and the stimulated lymphocyte production of IFN- $\gamma$ was determined following whole blood culture. Duplicate $1.48 \mathrm{ml}$ aliquots of heparinized blood were cultured in sterile 24-well flat culture plates (Sarstedt Ltd., Drinagh, Wexford, Ireland) with $20 \mu \mathrm{l}$ of PBS (GibcoBRL, Life Technologies Ltd., Paisley, Scotland) containing either $1 \mathrm{mg} / \mathrm{ml}$ of PHA (Sigma-Aldrich, Inc., St. Louis, MO, product No. L-9132) or $1 \mathrm{mg} / \mathrm{ml}$ of Concanavalin A (Con A; Sigma-Aldrich; product No. C 5275) or no additive for $24 \mathrm{~h}$ at $37{ }^{\circ} \mathrm{C}$ in an atmosphere of $5 \%$ $\mathrm{CO}_{2}$. Aseptic techniques were practised during this procedure under laminar flow conditions. The culture plates were then centrifuged at $1600 \times g$, at $4{ }^{\circ} \mathrm{C}$ for $20 \mathrm{~min}$; the supernatant was harvested and frozen at $-20{ }^{\circ} \mathrm{C}$ until it was assayed for IFN- $\gamma$ production, using an ELISA procedure [27] (Bovigam, CSL Biosciences, Victoria, Australia; catalogue No. 03000201). The in vitro phytohemagglutinin (PHA)- and Con A-stimulated IFN- $\gamma$ production was calculated by subtracting the absorbance at $450 \mathrm{~nm}$ of wells that received PBS alone from the absorbance of wells that received either PHA or Con A [29].

\section{Physical characteristics of the mats}

The mats were tested to give an assessment of physical parameters: hardness, simulated hoof-mat contact properties and time dependent deformation characteristics at the German Institute for Rubber Technology, (Hannover [DIK]). The proprietary mats, hereafter referred to as Mats 1, 2, and 3, were compared. Testing conformed to current ISO international standards. Each mat had its own distinct pattern on the mat upper surface which would inevitably have had some minor influence on physical test results. Mats 1 and 2 were predominantly made of natural rubber (NR) and Mat 3 comprised a modified ethylene vinyl acetate (EVA) foam structure.

\section{Shore A hardness}

The Shore hardness test for rubber samples is basically a method of indirectly characterising the elastic modulus of a rubber by measuring the elastic indentation caused by a rigid indentor pressed into the surface under specified loading conditions. Theoretically, hardness values range from zero degrees when the modulus is zero, (very soft rubber) up to $100^{\circ}$ where the modulus is infinitely high. The Shore A hardness of each sample was measured at room temperature and on a stand mounted digital Shore meter with a timer allowing the values of hardness to be determined consistently throughout testing. In each test a reading of hardness was taken after a $3 \mathrm{~s}$ constant force application of a standard indentor to a $6 \mathrm{~mm}$ thick specimen prepared in each instance from an actual mat. The values shown in Table 1 were an average of five tests, taken on different parts of the specimen prepared from the mat, but at least $12 \mathrm{~mm}$ from the edge of the specimen in all tests. This procedure complies with test standard ISO 7619:1997 (Rubber-determination of indentation hardness by means of pocket hardness meters).

\section{Friction measurements}

The characterisation of friction coefficients was carried out using a Zwick universal testing machine (Type 1445.17 , fitted with a $5 \mathrm{kN}$ load cell) which was modified to encompass friction measurements. The tests were conducted over a range of sliding velocities from 0.1 to $30 \mathrm{~mm} / \mathrm{min}$ and under an applied stress of $18.4 \mathrm{kPa}$. Under the range of sliding velocities any local interfacial thermal effects due to contact between the mat and the testing surface was negligible. Also, the amount of abrasion of the specimens was minimised by the selection of a low load.

The test specimens used were cut from actual mats and measured $40 \times 40 \mathrm{~mm}^{2}$ with a thickness equal to the mat under test. The specimens were bonded to an aluminium alloy plate which was loaded with a $3 \mathrm{~kg}$ mass. The plate was then drawn by a stranded steel wire which traversed two pulleys, one of which was connected to the $5 \mathrm{kN}$ load cell allowing the friction force to be measured directly. All tests were carried out at room temperature. For wet friction testing, a consistent level of wetness was ensured

Table 1 Results from the various tests that were used to characterise the physical properties of the mats

\begin{tabular}{llll}
\hline & Mat 1 & Mat 2 & Mat 3 \\
\hline Mean Shore A hardness ( \pm SE) & $64(0.16)$ & $70(0.22)$ & $61(0.16)$ \\
Mean wet friction $(\mu)^{*}$ & 0.59 & 0.63 & 0.38 \\
$\quad$ Maximum) & $(0.67)$ & $(0.70)$ & $(0.40)$ \\
(Minimum) & $(0.53)$ & $(0.57)$ & $(0.37)$ \\
$( \pm$ SE) & $(0.04)$ & $(0.04)$ & $(0.01)$ \\
Mean dry friction $(\mu)^{*}$ & 0.71 & 0.74 & 0.40 \\
$\quad$ Maximum) & $(0.74)$ & $(0.76)$ & $(0.43)$ \\
(Minimum) & $(0.67)$ & $(0.72)$ & $(0.38)$ \\
$\quad( \pm$ SE) & $(0.02)$ & $(0.01)$ & $(0.02)$ \\
Compression (mm) & & & \\
As result of applied stress equivalent to & 0.839 & 1.090 & 0.933 \\
$\quad$ application of one hoof & & & \\
Creep (mm) & & & \\
As result of an applied stress equivalent & 0.095 & 0.138 & 0.292 \\
$\quad$ to the application of one hoof for 300 s & & & \\
\hline
\end{tabular}

* The mean values of $\mu$ displayed are calculated from the three lowest sliding velocities as illustrated in Figs. 1 and 2. This was conducted to eliminate the effect of the phenomenon known as "stick slip" which was a characteristic of the test apparatus rather than of the test materials 
by the sample being immersed in a water/detergent (95:5) mixture for each test. Friction tests conformed to an adaptation of ISO 15113:1999, Rubber-determination of frictional properties.

\section{Dry and wet friction}

Samples of Mat 1, Mat 2 and Mat 3 were drawn over the test track surface. Initially the friction force peaked at a point where the adhesion force between the sample and surface began to break down and subsequently a slightly lower approximately constant frictional force was measured as the specimen travelled along the test track. This constant force is termed $\mathrm{F}_{\text {const }}$ and the friction coefficient was calculated from.

$$
\mu=\mathrm{F}_{\text {const }} / \mathrm{F}_{\mathrm{N}}
$$

where $\mu$ is the coefficient of friction and $F_{N}$ is the normal force.

The test was repeated four times at each sliding velocity in planes normal to and in line with the mat surface patterns. An average friction coefficient was calculated for each material and sliding velocity (i.e. eight tests per quoted coefficient of friction).

\section{Compression creep tests}

The mats were subjected to a compression creep test on an MTS 831.50 elastomer testing system $(2.5 \mathrm{kN}$ load cell). This test was devised specifically to render useful data in respect of time dependent properties for each product. A force was applied through two flat plates, approximately equivalent to that which a finishing steer would typically exert on a mat due to the downward load transmitted through one hoof. This force was maintained for a period of $300 \mathrm{~s}$ to examine how the reaction force in the region of contact on the mat relaxed with time. The applied stress was calculated from an average animal mass $(625 \mathrm{~kg})$ divided by four and the surface area of a typical hoof $\left(5300 \mathrm{~mm}^{2}\right)$ as specified by Kirchner and Boxberger [30].

\section{Statistical analysis}

All statistical analyses were performed using SAS software Version 9.3 (SAS Institute Inc. Cary, NC, USA). The pen was the experimental unit for all variables. Data were checked for normality and homogeneity of variance by histograms, q-q plots, and formal statistical tests as part of the UNIVARIATE procedure of SAS (version 9.3; SAS Institute, 2006). Data that were not normally distributed were transformed by raising the variable to the power of lambda. The appropriate lambda value was obtained by conducting a Box-Cox transformation analysis using the TRANSREG procedure of SAS. Data subjected to transformation were used to calculate P-values. Data from the three concrete slat treatments were analysed using a mixed model ANOVA with the MIXED procedure of SAS to examine the effect of treatment on intake, performance traits, hoof lesion scores, physiological and behavioural data. The PDIFF option was applied to evaluate the pairwise comparisons between the OWP treatment and the concrete slat treatment. The statistical model included the fixed effect of treatment and batch. Data with multiple observations, such as dirt scores, haematological variables and metabolites, were analysed using a repeated measures ANOVA (MIXED procedure of SAS 9.3). Terms for treatment, day and their interaction were included in the model. If the interaction term was not significant $(\mathrm{P}>0.05)$ it was subsequently excluded from the final model. The PDIFF option and the Tukey test were applied as appropriate to evaluate pair-wise comparisons between the group means on concrete slats and the associated $\mathrm{P}$ values were derived. Data were considered statistically significant when $\mathrm{P}<0.05$. Least square means (Lsmeans) are reported with standard error of the mean.

\section{Results \\ Characteristics of mats Shore A hardness}

The mean $( \pm \mathrm{SE})$ Shore A hardness for the three mat types were: Mat 1, 64 (0.16); Mat 2, 70 (0.22); Mat 3, 61 (0.16), respectively (Table 1 ).

\section{Wet and dry friction results}

A high friction coefficient for both wet and dry conditions is desirable between the hoof of the animal and the rubber mat. The higher the friction coefficient the less likely the animal is to slip when moving about in the pen, which will obviously provide a more comfortable environment for the animal. When the animal has firm and secure footing it will be more likely to move about its environment in a more natural manner to feed as desired without risk of slippage and sustaining injury.

The wet friction results are the most relevant for the normal environment encountered by the mats (Table 1 ). Figure 1 shows the results of the wet friction tests where, as stated previously, the test track was immersed in water with a $5 \%$ detergent mix. There is a clear difference in the friction coefficients for each material with some stickslip behaviour having a pronounced influence, notably where friction coefficients for Mat 2 declined at greater sliding velocities.

Dry friction test results are shown in Table 1 and Fig. 2 and it was observed that Mats 1 and 2 experienced some stick-slip behaviour at greater velocities. Consistently in both the wet and dry friction tests, the ranking order was Mat 2, Mat 1 and Mat 3 (i.e. Mat 2 was shown to have the highest and Mat 3 the lowest coefficient of sliding friction 
in contact with a constant rigid surface). Thus Mat 2 exhibited superior friction properties to the other mats tested.

\section{Compression creep tests}

The results from the compression creep tests are summarised in Fig. 3. Creep behaviour from a zero datum after the $2 \mathrm{~s}$ load application are presented in Fig. 4.

\section{Environmental conditions}

The mean $( \pm \mathrm{SE})$ daily air temperature $\left({ }^{\circ} \mathrm{C}\right)$ recorded in the shed facility (from November to May) was $9.9(0.03)$ $(\min 1.7 \max 22.4)$ and $6.6(0.04)(\min -5.2 ; \max 22.6)$ for the ambient (outside) temperature.

\section{Animal diet}

The mean $( \pm \mathrm{SE})$ chemical composition and nutritive value of the TMR offered to animals was: crude ash $81.4 \mathrm{~g} / \mathrm{kg}$ DM (2.09), crude protein $149.8 \mathrm{~g} / \mathrm{kg}$ DM (1.52), in vitro DM digestibility (DMD) $798.1 \mathrm{~g} / \mathrm{kg}$ (4.03), neutral detergent fibre (NDF) $450.4 \mathrm{~g} / \mathrm{kg} \mathrm{DM} \mathrm{(5.0),} \mathrm{pH} 4.2$ (0.03).

\section{Animal cleanliness}

There was a significant treatment, day and treatment $\times$ day interaction $(\mathrm{P}<0.05)$ for dirt score (Table 2). Dirt scores did not differ $(\mathrm{P}>0.05)$ between mat or slat treatments but were lower $(\mathrm{P}<0.05)$ than for the OWP treatment with an overall significant treatment $\times$ day interaction $(\mathrm{P}<0.001)$. Dirt scores were greater $(\mathrm{P}<0.05)$ on OWPs on days 42 , $84,105,126$ and 150 compared with slats.

\section{Animal health, performance, and hoof lesions}

No animal presented with clinical signs of bovine respiratory disease or required veterinary treatment for any ailment throughout the study period. The daily live weight gain of animals on the OWPs was greater for animals on the OWP compared with animals housed on slats and on Mat 2; Mat 1 and Mat 3 were not different from the other treatments (Table 3). However, carcass weight, kill out proportion, carcass fat score, carcass composition score and FCR were similar among treatments (Table 3). Animals on the OWPs had a greater $(\mathrm{P}<0.05)$ dry matter $(\mathrm{DM})$ feed intake compared with animals on the slat and the three mat types (Table 3 ). DMI was similar $(\mathrm{P}>0.05)$ between the slat and mat treatments. The number of hoof lesions was greater on all mat types $(\mathrm{P}<0.05)$ compared with concrete slats and OWP treatments (Table 3 ).

\section{Animal behaviour}

Overall (period 1-6 combined), the percentage of animals lying at any one time, was greater $(\mathrm{P}<0.05)$ in the animals housed on concrete slats, mats 1,2 and 3 compared with the animals housed on the OWPs (Table 3 ). The percentage of animals eating at any one time was lower $(\mathrm{P}<0.05)$ on concrete slats and Mat 2 compared with OWPs. The percentage of animals drinking at any one time was lower on OWPs compared with concrete slats and Mat 2 and was not different from Mat 1 and Mat 3.

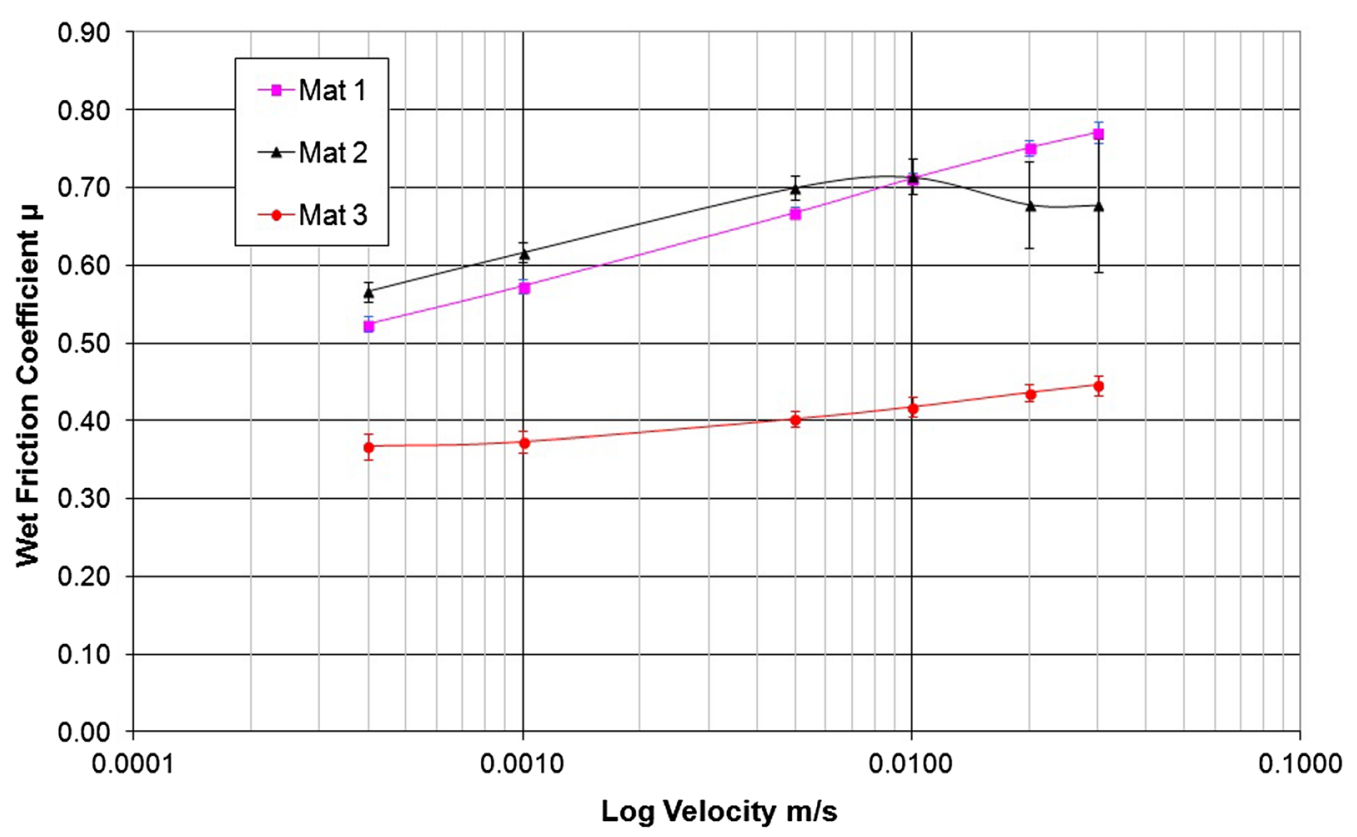

Fig. 1 Wet friction values measured for a range of sliding velocities 


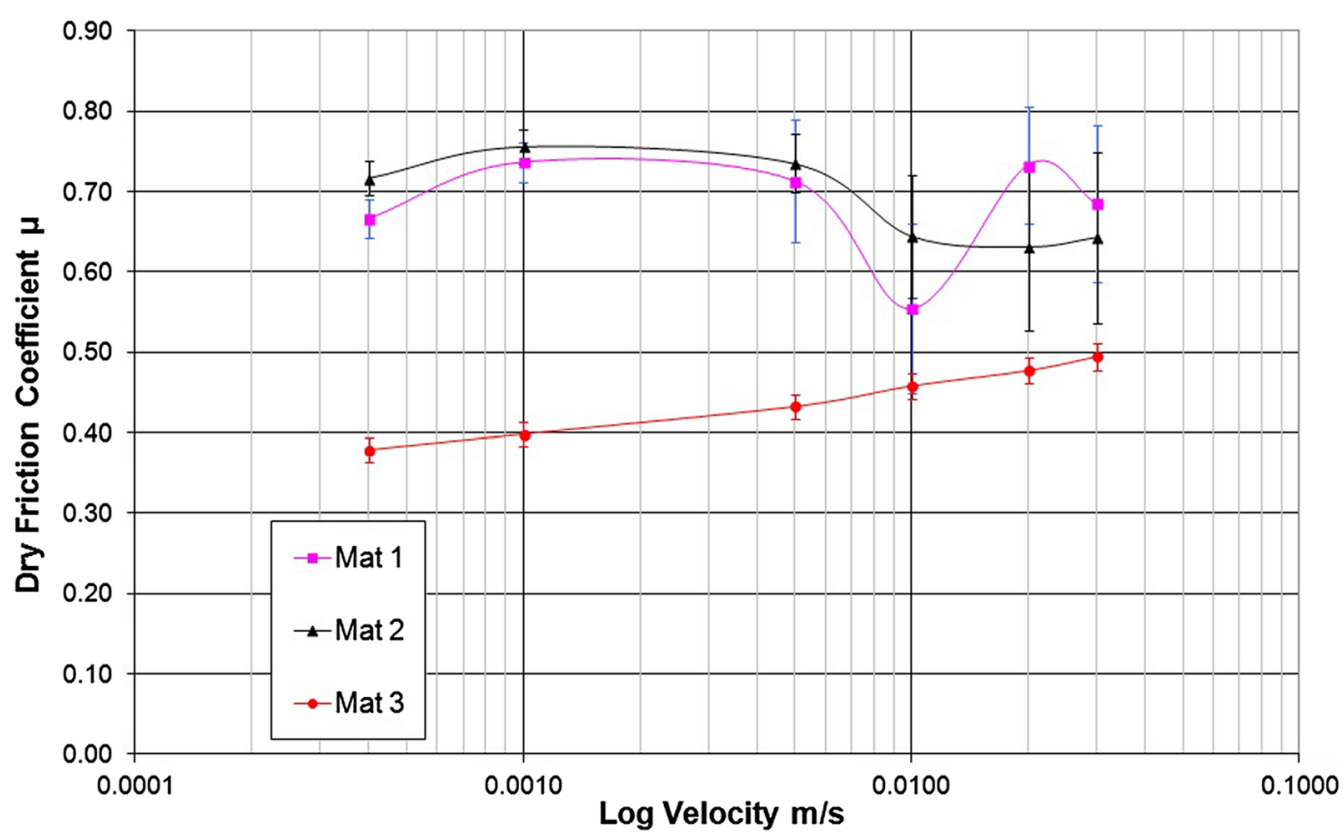

Fig. 2 Dry friction values measured for a range of sliding velocities

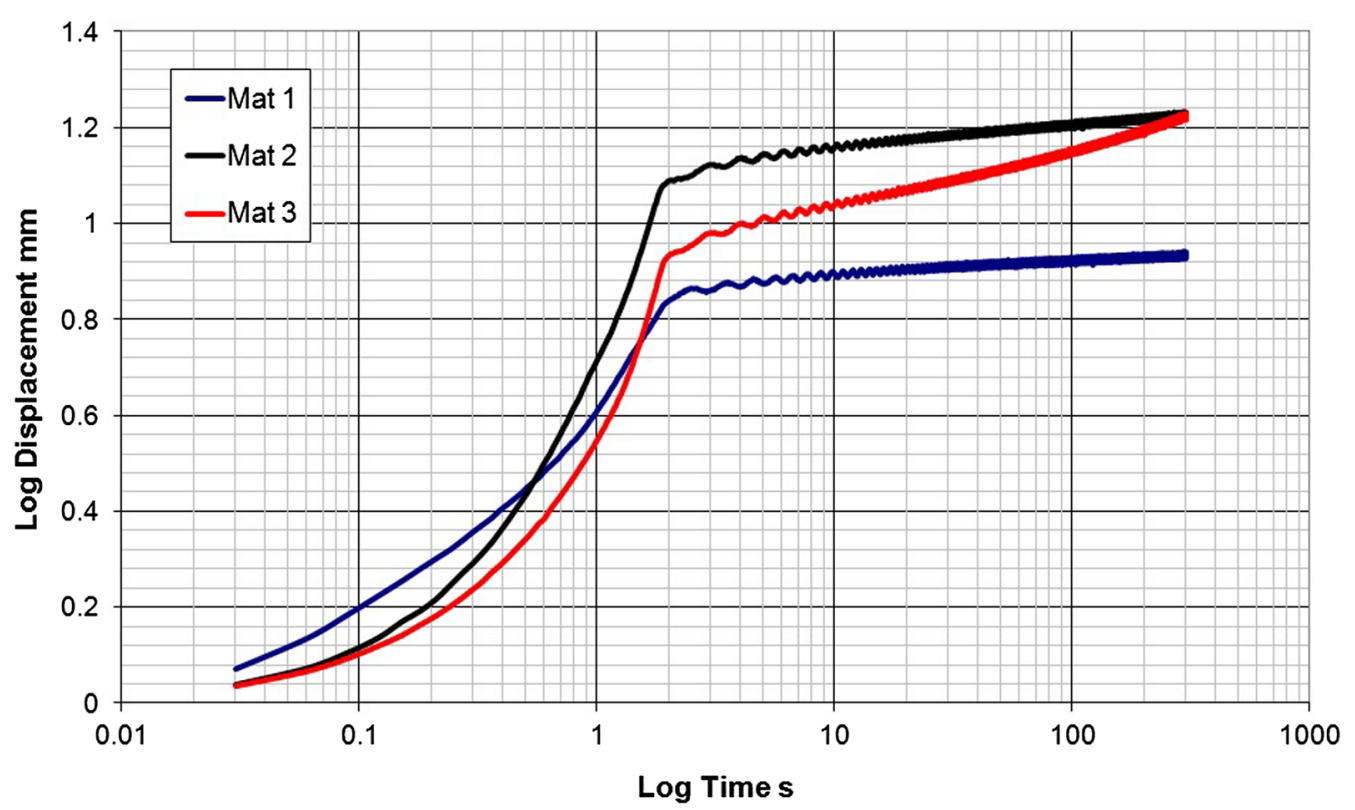

Fig. 3 Graph showing results of compression tests where a stress equivalent to that exerted by a single hoof exerted upon the Mat

\section{Physiological variables}

There was no effect of treatment or treatment $\times$ day interaction $(\mathrm{P}>0.05)$ for plasma concentrations of albumin, total protein, $\beta \mathrm{HB}$, NEFA, glucose, fibrinogen, haptoglobin, Con-A, PHA-induced IFN- $\gamma$ and CK activity (Table 4). Day of sampling was significant $(\mathrm{P}<0.05)$ for plasma concentrations of albumin, $\beta \mathrm{HB}, \mathrm{NEFA}$, glucose, fibrinogen, haptoglobin, PHA-induced-IFN- $\gamma$ production and CK activity.

\section{Haematological variables}

There was no effect of treatment or treatment $\times$ day interactions $(\mathrm{P}>0.05)$ whereas day $(\mathrm{P}<0.05)$ was significant for basophil, eosinophil, leukocyte, lymphocyte, 


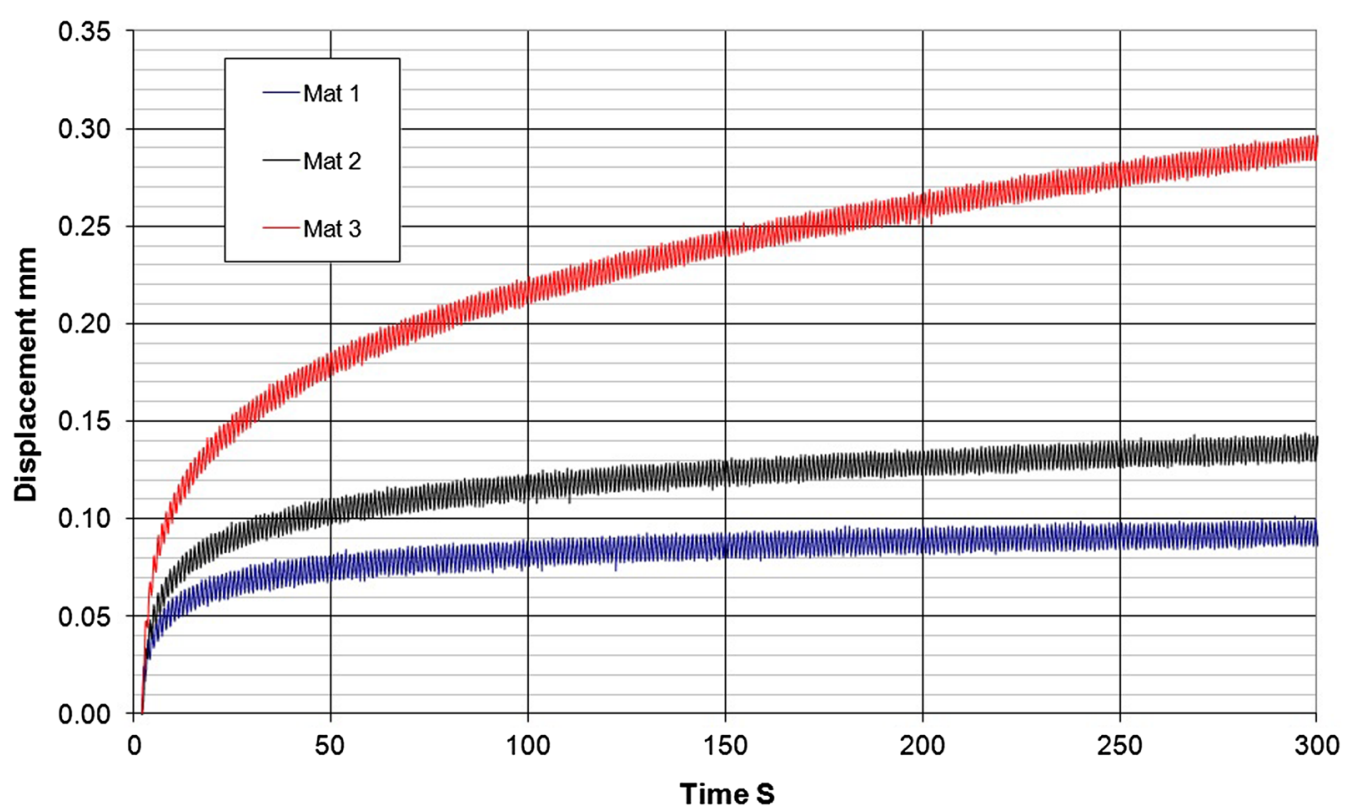

Fig. 4 Graph showing the results of creep tests where a stress equivalent to that exerted by one hoof was maintained on the Mat for $300 \mathrm{~s}$

Table 2 Cleanliness scores of finishing beef steers on concrete slats, Mat 1, Mat 2, Mat 3 and OWP's from day 0 to day 150. Values are expressed as Lsmeans ( \pm SE)

\begin{tabular}{|c|c|c|c|c|c|c|c|c|c|}
\hline & d 0 & d 21 & d 42 & d 63 & d 84 & d 105 & d 126 & d 150 & SE \\
\hline Concrete slats & $37^{a}$ & 45 & $48^{x}$ & 43 & $39^{x}$ & $34^{x}$ & $27^{b, x}$ & $23^{b, x}$ & 0.112 \\
\hline Mat 1 & $37^{a}$ & $45^{b}$ & 48 & 46 & 41 & 33 & $24^{b}$ & $21^{\mathrm{b}}$ & 0.112 \\
\hline Mat 2 & $36^{a}$ & $47^{b}$ & $50^{b}$ & $46^{b}$ & 43 & 35 & $27^{b}$ & $22^{\mathrm{b}}$ & 0.112 \\
\hline Mat 3 & $37^{a}$ & 48 & $51^{b}$ & $49^{b}$ & 44 & 34 & $26^{\mathrm{b}}$ & $22^{\mathrm{b}}$ & 0.112 \\
\hline OWP's & $35^{\mathrm{a}}$ & 43 & $55^{\text {by }}$ & 42 & $57^{\mathrm{b}, \mathrm{y}}$ & $48^{\mathrm{b}, \mathrm{y}}$ & $40^{y}$ & $32^{y}$ & 0.112 \\
\hline
\end{tabular}

Sum of 16 body parts each on a cleanliness scale of 1 (clean) to 5 (dirty)

Interactions; Treatment $\mathrm{P}=0.006$; Day $\mathrm{P}<0.001$; Treatment $\times$ day $\mathrm{P}<0.001$

$\mathrm{a}, \mathrm{b}$ Lsmeans (in rows) that do not have a common superscript differ by $\mathrm{P}<0.05$

$x, y$ Lsmeans (in columns) that do not have a common superscript differ by $P<0.05$

monocyte, neutrophil, red blood cell number, haemoglobin concentration and haematocrit percentage (Table 5). There was no effect of treatment, sampling day or treatment $x$ day interaction $(\mathrm{P}>0.05)$ for white blood cell number.

\section{Discussion}

In the present study, measuring the responses of animals to the different floor types, in terms of performance, hoof score, dirt scores, behaviour, immunological and physiological variables provided an insight into how the animals were coping. The objective of this study was to explore, in systematic fashion, factors affecting the overall performance, and welfare of animals housed on different floor types. The rationale for using
TMR feeding was to achieve a relatively stable rumen $\mathrm{pH}$ and fermentation pattern throughout the day. This has been reported to promote better cellulose digestion and a greater lipogenic to non-lipogenic volatile fatty acid (VFA) ratio [31, 32]. Animals on the OWPs had a greater live weight gain compared with the slat and Mat 2 treatments: Mat 1 and Mat 3 were the same as the other treatments. Interestingly, carcass weight, kill out proportion, carcass fat score, carcass composition score and FCR were similar among treatments. The similar carcass weight for animals on the slat treatment in the present study is consistent with other studies in Ireland examining the performance and carcass characteristics of finishing animals housed on concrete slats and fed similar diets [32-38]. 
Table 3 Intake, performance, slaughter traits, hoof scores, behaviour of finishing beef steers housed on concrete slats, Mat 1, Mat 2, Mat 3 and OWP's

\begin{tabular}{|c|c|c|c|c|c|c|c|}
\hline & Concrete slats & Mat 1 & Mat 2 & Mat 3 & OWP's & SE & Significance \\
\hline Initial weight (kg) & 538.4 & 538.4 & 538.4 & 538.4 & 539.1 & 9.40 & NS \\
\hline Final weight (kg) & 677.2 & 693.4 & 676.1 & 682.6 & 699.5 & 7.37 & NS \\
\hline Carcass (kg) & 371.9 & 385.8 & 374.7 & 381.1 & 384.7 & 5.00 & NS \\
\hline Live weight gain/day & $0.93^{\mathrm{a}}$ & 1.04 & $0.92^{\mathrm{a}}$ & 0.97 & $1.08^{\mathrm{b}}$ & 0.03 & $P=0.011$ \\
\hline Kill out proportion (KO) (\%) & 55.0 & 55.7 & 55.4 & 55.8 & 55.1 & 0.40 & NS \\
\hline Kidney and channel fat (kg) & 11.2 & 10.7 & 11.4 & 10.9 & 11.2 & 0.37 & NS \\
\hline Carcass composition score $^{1}$ & 9.0 & 9.5 & 8.8 & 9.1 & 9.4 & 0.23 & NS \\
\hline Carcass fat score ${ }^{2}$ & 10.7 & 10.7 & 10.9 & 10.8 & 10.7 & 0.22 & NS \\
\hline Dry matter intake (DMI) kg/animal/day & $9.1^{\mathrm{a}}$ & $9.3^{\mathrm{a}}$ & $9.2^{\mathrm{a}}$ & $9.2^{\mathrm{a}}$ & $10.1^{\mathrm{b}}$ & 0.09 & $P<0.001$ \\
\hline DMI/LWG & 9.9 & 9.0 & 10.0 & 9.5 & 9.5 & 0.34 & NS \\
\hline FCR (kg DMI/kg of LWG gained) $)^{3}$ & 9.9 & 9.0 & 10.0 & 9.5 & 9.5 & 0.35 & NS \\
\hline Hoof lesions ${ }^{4}$ & $20^{\mathrm{a}}$ & $33^{b}$ & $32^{\mathrm{b}}$ & $30^{b}$ & $24^{a, b}$ & 3.38 & $P=0.050$ \\
\hline Percent lying time (\%) & $49.4^{\mathrm{a}}$ & $47.2^{\mathrm{a}}$ & $48.7^{\mathrm{a}}$ & $45.2^{\mathrm{a}}$ & $38.0^{\mathrm{b}}$ & 1.11 & $P<0.001$ \\
\hline Percent eating (\%) & $18.1^{\mathrm{a}}$ & 20.6 & $18.0^{\mathrm{a}}$ & 20.9 & $22.1^{\mathrm{b}}$ & 0.94 & $P=0.003$ \\
\hline Percent drinking time (\%) & $0.60^{\mathrm{a}}$ & 0.48 & $0.54^{\mathrm{a}}$ & 0.51 & $0.38^{\mathrm{b}}$ & 0.04 & $P=0.010$ \\
\hline
\end{tabular}

Values are expressed as Lsmeans (SE)

NS not statistically significant

$\mathrm{a}, \mathrm{b}$ Lsmeans (in rows) that do not have a common superscript differ by $\mathrm{P}<0.05$

1 EU Beef Carcass Classification Scheme, scale 1 (poorest) to 15 (best)

2 EU Beef Carcass Classification Scheme, scale 1 (leanest) to 15 (fattest)

${ }^{3}$ FCR was expressed as kilogram carcass gain per $1000 \mathrm{~kg} \mathrm{DMI}$

4 The total number of hoof lesions/animal at the end of the study

Dry matter intake was greater in the OWPs compared with all other treatments, whereas feed conversion ratio (FCR) was similar across treatments. Studies comparing concrete slats with straw as underfoot conditions in pens for finishing bulls are often confounded by space allowance, as housing systems utilising straw, have a larger total floor area per animal than fully slatted pens [39]. Gygax et al. [40] examined the effects of four space allowances $\left(2.5,3.0,3.5\right.$ and $\left.4.0 \mathrm{~m}^{2}\right)$ on the behaviour and cleanliness of finishing bulls on fully slatted rubber coated floors and concluded that that increasing space allowance had several beneficial and no negative effects on welfare indicators. In the present study, dirt scores were greater on the OWPs compared with all other treatments. Additionally, animals on the OWPs spent less time lying compared with all treatments. It is reported in the literature that cattle housed on concrete floors tended to lie down or stand up less frequently and displayed more abnormal movements than animals housed on straw $[2-4,13,18$, $41,42]$. Bulls housed on slatted floors were reported to be more hesitant about lying down and were more likely to lie down via the "dog-sitting" position [43]. In addition, Graf [2] recorded a greater incidence of abnormal lying down movements among bulls on slatted concrete floors, but only at low space allowances.
A series of experiments examining the flooring preferences of cattle were conducted by Irps [44, 45]. In one study [44] 15-mo-old cattle spent more time lying on a straw-covered area than on rubber-coated concrete slats and spent the least time lying on uncovered concrete slats when they had access to all three areas. However, when lying times for fattening bulls were measured across three pens, one with rubber-coated concrete slats, one with $50 \%$ rubber-coated and $50 \%$ plain concrete slats and one with $100 \%$ plain concrete slats, there were no differences in lying times across the three systems [46]. Rubber coated slatted floors have been tested as an alternative floor quality in housing systems for finishing bulls [5, 39, $40]$ and the results indicate that finishing bulls lie down more frequently, slip less and have fewer hock lesions compared with fully slatted concrete floors. Interestingly, Elmore et al. [1] reported that flooring substrate had a large impact on health, hygiene, and postural changes of finishing beef steers, though there was no effect of flooring treatment on time budget behaviour or performance data. In the present study, the number of hoof lesions was greater on all mat types compared with concrete slats and OWP treatments. Although significant differences in numbers of lesions were found, the lesions were not severe enough to be biologically meaningful in terms 
Table 4 Plasma metabolic variables (albumin, globulin, total protein, $\beta H B$, NEFA, Glucose, creatine kinase), acute phase proteins (fibrinogen, haptoglobin) and immune variables Concanavalin-A (Con-A) induced and Phytohaemagglutinin (PHA) induced interferon- $\gamma$ (IFN- $\gamma$ ) of finishing beef steers on day 0 and day 150

\begin{tabular}{|c|c|c|c|c|c|c|c|c|c|c|}
\hline & Bleed & $\begin{array}{l}\text { Concrete } \\
\text { slats }\end{array}$ & Mat 1 & Mat 2 & Mat 3 & OWP & SE & Treatment (T) & Day (D) & $T \times D$ \\
\hline Albumin & d 0 & $32.64^{a}$ & $32.44^{\mathrm{a}}$ & $32.90^{\mathrm{a}}$ & $32.56^{\mathrm{a}}$ & $32.81^{a}$ & 0.143 & NS & $P<0.05$ & NS \\
\hline$(g / l)$ & d 150 & $34.16^{b}$ & $34.63^{b}$ & $34.23^{b}$ & $34.54^{b}$ & $34.01^{b}$ & 0.192 & & & \\
\hline Globulin & d 0 & 41.43 & 41.58 & 41.83 & 41.68 & 42.19 & 0.515 & NS & NS & NS \\
\hline$(g / l)$ & d 150 & 41.02 & 39.92 & 40.59 & 40.39 & 38.88 & 0.505 & & & \\
\hline Total protein & d 0 & 74.06 & 74.02 & 74.72 & 74.24 & 74.99 & 0.552 & NS & NS & NS \\
\hline$(g / l)$ & d 150 & 75.18 & 74.55 & 74.82 & 74.93 & 72.88 & 0.456 & & & \\
\hline$\beta H B$ & d 0 & $0.27^{\mathrm{a}}$ & $0.27^{a}$ & $0.29^{a}$ & $0.27^{a}$ & 0.29 & 0.01 & NS & $P<0.05$ & NS \\
\hline$(\mathrm{mmol} / \mathrm{l})$ & d 150 & $0.23^{b}$ & $0.23^{b}$ & $0.23^{b}$ & $0.22^{b}$ & 0.28 & 0.01 & & & \\
\hline NEFA & d 0 & 0.15 & 0.17 & 0.17 & 0.19 & $0.22^{a}$ & 0.01 & NS & $P<0.05$ & NS \\
\hline (mmol/l) & d 150 & 0.16 & 0.18 & 0.15 & 0.16 & $0.13^{b}$ & 0.01 & & & \\
\hline Glucose & $\mathrm{d} 0$ & $3.98^{\mathrm{a}}$ & $3.93^{\mathrm{a}}$ & $4.05^{\mathrm{a}}$ & $4.01^{a}$ & 3.99 & 0.03 & NS & $P<0.05$ & NS \\
\hline$(\mathrm{mmol} / \mathrm{l})$ & d 150 & $4.29^{b}$ & $4.21^{b}$ & $4.30^{b}$ & $4.34^{b}$ & 4.12 & 0.03 & & & \\
\hline Creatine kinase & d 0 & $273.5^{\mathrm{a}}$ & $255.8^{\mathrm{a}}$ & $266.0^{a}$ & $244.0^{a}$ & $321.8^{a}$ & 11.86 & NS & $P<0.05$ & NS \\
\hline$(\mathrm{U} / \mathrm{I})$ & d 150 & $165.9^{b}$ & $183.3^{b}$ & $159.3^{b}$ & $166.3^{b}$ & $173.8^{b}$ & 7.18 & & & \\
\hline Fibrinogen & $\mathrm{d} 0$ & $489.0^{\mathrm{a}}$ & $483.2^{\mathrm{a}}$ & $502.3^{a}$ & $498.6^{a}$ & $511.0^{\mathrm{a}}$ & 11.04 & NS & $P<0.05$ & NS \\
\hline$(\mathrm{mg} / \mathrm{dl})$ & d 150 & $382.3^{b}$ & $366.0^{b}$ & $364.2^{b}$ & $348.1^{b}$ & $351.2^{b}$ & 8.46 & & & \\
\hline Haptoglobin & d 0 & $0.75^{\mathrm{a}}$ & $0.75^{\mathrm{a}}$ & $0.76^{\mathrm{a}}$ & $0.77^{\mathrm{a}}$ & $0.78^{\mathrm{a}}$ & 0.02 & NS & $P<0.05$ & NS \\
\hline ( $\mathrm{g}$ of $\mathrm{Hb}$ binding capacity/l) & d 150 & $0.64^{b}$ & $0.58^{b}$ & $0.62^{b}$ & $0.58^{b}$ & $0.55^{b}$ & 0.01 & & & \\
\hline Concanavalin-A (CON-A) induced IFN- $\gamma$ & d 0 & 1.04 & 1.03 & 0.83 & 0.98 & 0.93 & 0.10 & NS & NS & NS \\
\hline Absorbance@450 nm & d 150 & 0.95 & 1.05 & 0.84 & 1.07 & 0.93 & 0.11 & & & \\
\hline Phytohaemagglutinin (PHA) induced IFN- $\gamma$ & d 0 & $0.90^{a}$ & $0.83^{\mathrm{a}}$ & $1.06^{\mathrm{a}}$ & $0.91^{\mathrm{a}}$ & $0.81^{\mathrm{a}}$ & 0.09 & NS & $P<0.05$ & NS \\
\hline Absorbance @450 nm & d 150 & $0.48^{b}$ & $0.52^{b}$ & $0.59^{b}$ & $0.59^{b}$ & $0.58^{b}$ & 0.06 & & & \\
\hline
\end{tabular}

Values are expressed as Lsmeans (SE)

NS not statistically significant, $T$ Treatment, $D$ Day, $T \times D$ Treatment $\times$ day interaction

$\mathrm{a}, \mathrm{b}$ Lsmeans (in rows) that do not have a common superscript differ by $\mathrm{P}<0.05$

of lameness. No information is available on the effects of high friction floors on cattle locomotion. Phillips and Morris [47-49] and Phillips et al. [50] measured these variables in cows walking on floors with different levels of friction. Phillips and Morris [49] and Phillips et al. [50] reported that floor friction had a considerable impact on the walking pattern of cows. Cows walked quickly with frequent, short steps on low friction floors $(\mu<0.4)$. As $\mu$ increased to 0.5 (mean of static and sliding friction) with aggregates of 0.5 and $1.2 \mathrm{~mm}$, step length increased and the number of steps decreased in order to maintain speed. Increased $\mu$ also may increase the hanging limb phase at the expense of the supporting limb phase, to reduce friction, while maintaining a long stride. Their findings suggest that the optimum coefficient of friction for cattle floors is between 0.4 and 0.5 and significantly Web and Nilsson [51] reported that the incidence of slip increases rapidly as coefficients of static friction for floors decrease below 0.4 .
In the present study, the hardness values (Shore A scale measurements to ISO 7619) ranked the mats from hardest to softest (Mat 2, Mat 1, and Mat 3). The coefficients of friction were determined for each material in both wet and dry conditions on a roughened metal test track (an adaptation of ISO 15113). For both wet and dry tests, the ranking was Mat 2, Mat 1, and Mat 3 where the friction coefficients went from highest to lowest. In creep tests under constant compressive loading which replicated a typical stress resulting from the load transmitted under one hoof, the ranking order after load application was 3, 2, 1 (largest to smallest change in deformation). Mat 2 produced the highest coefficient of friction under both wet and dry conditions when subject to sliding motion in contact with a rigid surface. This is considered to be a positive characteristic in respect of comfort and safety and more likely to promote behaviour similar to that in the cow's outdoor environment. If a high coefficient of friction, high static and dynamic deformation and low 
Table 5 Haematological variables of finishing beef steers on day (0) and d 150

\begin{tabular}{|c|c|c|c|c|c|c|c|c|c|c|}
\hline & Bleed & $\begin{array}{l}\text { Concrete } \\
\text { slats }\end{array}$ & Mat 1 & Mat 2 & Mat 3 & OWP & SE & Treatment $(T)$ & Day (D) & $T \times D$ \\
\hline WBCP & d 0 & 9.11 & 9.46 & $9.19^{\mathrm{a}}$ & $9.61^{\mathrm{a}}$ & 9.60 & 0.163 & NS & $P<0.05$ & NS \\
\hline$\left(1 \times 10^{3} \mu \mathrm{l}\right)$ & d 150 & 8.85 & 9.03 & $8.66^{b}$ & $8.82^{b}$ & 9.82 & 0.166 & & & \\
\hline Basophil number & d 0 & $0.07^{\mathrm{a}}$ & $0.08^{\mathrm{a}}$ & $0.07^{\mathrm{a}}$ & $0.08^{\mathrm{a}}$ & $0.08^{\mathrm{a}}$ & $0.002^{\mathrm{a}}$ & NS & $P<0.05$ & NS \\
\hline$\left(1 \times 10^{3} \mu \mathrm{l}\right)$ & d 150 & $0.06^{\mathrm{b}}$ & $0.06^{b}$ & $0.06^{b}$ & $0.06^{b}$ & $0.06^{b}$ & $0.002^{b}$ & & & \\
\hline Eosinophil number & d 0 & $0.07^{\mathrm{a}}$ & $0.08^{\mathrm{a}}$ & $0.07^{\mathrm{a}}$ & $0.08^{\mathrm{a}}$ & $0.08^{\mathrm{a}}$ & 0.002 & NS & $P<0.05$ & NS \\
\hline$\left(1 \times 10^{3} \mu \mathrm{l}\right)$ & d 150 & $0.06^{\mathrm{b}}$ & $0.06^{b}$ & $0.06^{\mathrm{b}}$ & $0.06^{\mathrm{b}}$ & $0.06^{b}$ & 0.002 & & & \\
\hline Leukocyte number & d 0 & 0.07 & 0.05 & 0.06 & 0.05 & $0.09^{\mathrm{a}}$ & 0.005 & NS & $P<0.05$ & NS \\
\hline$\left(1 \times 10^{3} \mu l\right)$ & d 150 & 0.05 & 0.05 & 0.06 & 0.05 & $0.05^{b}$ & 0.003 & & & \\
\hline Lymphocyte number & d 0 & 5.29 & 5.24 & 5.11 & 5.58 & 5.47 & 0.098 & NS & $P<0.05$ & $P<0.064$ \\
\hline$\left(1 \times 10^{3} \mu \mathrm{l}\right)$ & d 150 & 5.67 & $5.73^{b}$ & 5.34 & 5.76 & $6.00^{b}$ & 0.100 & & & \\
\hline Monocyte number & d 0 & $0.55^{\mathrm{a}}$ & $0.57^{\mathrm{a}}$ & $0.49^{\mathrm{a}}$ & $0.54^{\mathrm{a}}$ & $0.52^{\mathrm{a}}$ & 0.014 & NS & $P<0.05$ & $P=0.036$ \\
\hline$\left(1 \times 10^{3} \mu l\right)$ & d 150 & $0.34^{b}$ & $0.38^{b}$ & $0.39^{b}$ & $0.37^{b}$ & $0.41^{b}$ & 0.009 & & & \\
\hline Neutrophil number & d 0 & 2.42 & $2.47^{\mathrm{a}}$ & 2.37 & 2.68 & 2.33 & 0.054 & NS & $P<0.05$ & NS \\
\hline$\left(1 \times 10^{3} \mu \mathrm{l}\right)$ & d 150 & 2.22 & $2.12^{\mathrm{b}}$ & 2.29 & 2.35 & 2.14 & 0.046 & & & \\
\hline Haematocrit & d 0 & $33.39^{a}$ & $33.10^{\mathrm{a}}$ & $33.22^{\mathrm{a}}$ & $32.27^{\mathrm{a}}$ & $33.72^{\mathrm{a}}$ & 0.36 & NS & $P<0.05$ & NS \\
\hline$\%$ & d 150 & $37.60^{b}$ & $37.45^{b}$ & $36.62^{b}$ & $37.00^{b}$ & $36.44^{b}$ & 0.24 & & & \\
\hline Platelet number & do & $447.9^{\mathrm{a}}$ & $464.1^{\mathrm{a}}$ & $484.2^{\mathrm{a}}$ & $485.8^{\mathrm{a}}$ & $457.3^{\mathrm{a}}$ & $8.65^{\mathrm{a}}$ & NS & $P<0.05$ & NS \\
\hline$\left(1 \times 10^{3} \mu \mathrm{l}\right)$ & d 150 & $203.4^{b}$ & $185.2^{b}$ & $192.2^{b}$ & $205.9^{b}$ & $195.4^{b}$ & $30.39^{b}$ & & & \\
\hline Red blood cell number & d 0 & $8.19^{\mathrm{a}}$ & $8.14^{\mathrm{a}}$ & 7.98 & $7.87^{\mathrm{a}}$ & 8.29 & 0.101 & NS & $P<0.05$ & NS \\
\hline$\left(1 \times 10^{3} \mu \mathrm{l}\right)$ & d 150 & $8.62^{b}$ & $8.62^{b}$ & 8.32 & $8.46^{\mathrm{b}}$ & 8.50 & 0.068 & & & \\
\hline Haemoglobin & d 0 & 12.95 & 12.84 & 12.86 & 12.61 & 13.21 & 0.149 & NS & NS & NS \\
\hline$(g / d l)$ & d 150 & 13.36 & 13.27 & 12.98 & 13.15 & 13.08 & 0.139 & & & \\
\hline
\end{tabular}

Values are expressed as Lsmeans (SE)

NS not statistically significant, $T$ Treatment, $D$ Day, $T \times D$ Treatment $\times$ day interaction

$\mathrm{a}, \mathrm{b}$ Lsmeans (in rows) that do not have a common superscript differ by $\mathrm{P}<0.05$

hardness were seen as desirable attributes for the mat materials and equal weighting is given to each property, there is little to choose between the performance of each mat.

Without devising specific tests, it is problematic to study the influence of dynamic and static friction when indentation of rubber takes place, as in the situation where a load is transmitted by a hoof. It is essential to minimise the influence of the dynamic properties of apparati if friction data is to be believed. Tests also need to quantify the contributions of bulk friction and adhesive friction [52]. Further research could shed light on these factors.

Alterations in the levels of blood cell constituents are indicative of an attempt to restore homeostasis when adverse physical conditions are encountered by an animal and thus, blood cells are very sensitive indicators of the patho-physiological responses of animals to a stressor [53].

In the present study, lymphocyte functional assays in terms of PHA-induced and Con A-induced IFN- $\gamma$ production were used to assess cell-mediated immune function. The results showed no change in immune response among treatments in response to stimulation in vitro with the two mitogens, $\mathrm{CON}-\mathrm{A}$ and $\mathrm{PHA}$, indicating that there was no impairment of immune responsiveness of animals on the slat compared with the other treatments. Induction of a proliferative response induced by antigen in vitro has been shown to be representative of cellular immunocompetence [24]. The secretion of IFN- $\gamma$ by lymphocytes is critically important in orchestrating an effective immune response, especially cellular immunity [29], and the induction of IFN- $\gamma$ by Con A and PHA lectins corresponds to the degree of blastogenesis in cattle [54]. In the present study, maintenance of homeostasis was not affected by floor type. There was no effect of floor type on blood metabolite concentrations; thus metabolic homeostasis was maintained across treatments and the metabolite concentrations in the present study were within the normal physiological ranges for cattle [55-57].

\section{Conclusions}

Steers on the OWPs had reduced lying percentage time compared with all the other treatments. Carcass weight, kill out proportion, carcass fat score, carcass composition score, and FCR, and physiological responses were 
similar among treatments. No incidence of laminitis was observed among treatments. There were a greater number of lesions on the hooves of animals housed on mats compared with bare concrete slats and OWP treatments. Therefore, under appropriate environmental conditions, out-wintering steers on OWP's is a good alternative to wintering indoors on bare concrete slats. However, dirt scores were greater for animals on OWPs on days 42, 84, 105, 126 and 150 compared with slats. Under the conditions of the present study, there is no evidence to suggest that animals housed on bare concrete slats are at an animal welfare disadvantage compared with other floor treatments.

\begin{abstract}
Abbreviations
ADF: acid detergent fibre; bHB: beta hydroxy butyrate; CCTV: close circuit television. CK: creatine kinase; Con-A: concanavalin-A; DM: dry matter; DMD: dry matter digestibility; DMI: dry matter intake; IFN-y: interferon- - ; Lsmeans: least square means; PHA: phytohaemagglutinin A; FCR: feed conversion ratio; NEFA: non-esterified fatty acids; NS: not statistically significant; RBC: red blood cell; SD: standard deviation; SE: standard error; TMR: total mixed ration; WBC: white blood cell.
\end{abstract}

\section{Authors' contributions}

$B E$ and EOR designed and planned the study and all authors drafted the manuscript. BE performed the statistical analysis. BE, EOR, JDMCN, SJ participated in interpretation of data. All authors read and approved the final manuscript.

\section{Author details}

${ }^{1}$ Animal and Bioscience Research Department, Animal \& Grassland Research and Innovation Centre, Teagasc, Grange, Dunsany, Co. Meath C15 PW93, Ireland. ${ }^{2}$ Centre for Elastomer Research (CER), School of Manufacturing and Design Engineering, Dublin Institute of Technology (DIT), Dublin, Ireland ${ }^{3}$ Livestock Systems Research, Department Animal \& Grassland Research and Innovation Centre, Teagasc, Grange, Dunsany, Co. Meath C15 PW93, Ireland.

\section{Acknowledgements}

The authors thank: Francis Collier, Joe Larkin, Eddie Mulligan, Margaret Murray and Dan Prendiville for excellent technical help and assistance during the study; the farm staff (Seamus Fagan, Liam Kirk, Hugh Mulligan) at Teagasc, Grange, for care and management of the animals; the advice and use of physical test facilities provided by Dr. Thomas Alshuth and Peter Erren of the Deutsches Institut für Kautschuktechnologie e.V. (DIK, Hannover, Germany).

\section{Competing interests}

The authors declare that they have no competing interests.

\section{Ethical considerations}

The study was planned and performed in a manner intended to prevent any unnecessary pain and discomfort to the animals. All animal procedures performed in this study were conducted under experimental licence (B100/2869) from the Irish Department of Health and Children in accordance with the Cruelty to Animals Act 1876 and the European Communities (Amendment of Cruelty to Animals Act 1876) Regulation 2002 and 2005.

\section{Publisher's Note}

Springer Nature remains neutral with regard to jurisdictional claims in published maps and institutional affiliations.

Received: 24 January 2017 Accepted: 19 May 2017

Published online: 30 May 2017

\section{References}

1. Elmore MR, Elischer MF, Claeys MC, Pajor EA. The effects of different flooring types on the behavior, health, and welfare of finishing beef steers. J Anim Sci. 2015;93(3):1258-66.

2. Graf B. Spaltenbodenhaltung bei mastochsen. Landbauforschung Volkenrode Sonderheft. 1979;48:73-88.

3. Graf B. Inwieweit genu" gen Laufstallsysteme den artspezifischen Anspru" chen von Mastrindern? U" berpru" fung anhand von Merkmalen des Ausruhverhaltens. In: Aktuelle Arbeiten zur artgema"ßen Tierhaltung 299, KTBL-Schrift. 1984. p. 9-13.

4. Der Graf B. Einfluss unterschiedlicher Laufstallsysteme auf Verhaltensmerkmale von Matschen. Eidgenossichen Technishen Hochschule: Zurich; 1984. p. 282.

5. Ruis-Heutinck LFM, Smits MCJ, Smits AC, Heeres JJ. Effects of floor type and floor area on behaviour and carpal joint lesions in beef bulls. Improving health and welfare in animal production. In: Proceedings of sessions of the EAAP Commission on Animal Management \& Health. The Hague. 21-24 August 2000.

6. Schrader L, Roth H-R, Winterling C, Brodmann N, Langhans W, Geyer H, Graf B. The occurrence of tail tip alterations in fattening bulls kept under different husbandry conditions. Anim Wel. 2001;10:119-30.

7. Schulze Westerath H, Gygax L, Mayer C, Wechsler B. Leg lesions and cleanliness of finishing bulls kept in housing systems with different lying area surfaces. The Vet J. 2007;174:77-85.

8. Mayer C, Thio T, Westerath HS, Ossent P, Gygax L, Wechsler B, Friedli K. Vergleich von Betonspaltenbo" den, gummimodifizierten Spaltenbo"den und Buchten mit Einstreu in der Bullenmast unter dem Gesichtspunkt der Tiergerechtheit. Landbauforschung Vo"lkenrode-FAL Agricultural Research, Sonderheft. 2007. p 303 .

9. Absmanner E, Rouha-Mülleder C, Scharl T, Leisch F, Troxler J. Effects of different housing systems on the behaviour of beef bulls-an on-farm assessment on Austrian farms. Appl Anim Behav Sci. 2009;1 18:12-9.

10. Ingvartsen $\mathrm{KL}$, Andersen HR. Space allowance and type of housing for growing cattle. Acta Agr Scand A Anim. 1993;43:65-80.

11. Fisher AD, Crowe MA, Prendiville DJ, Enright WJ. Indoor space allowance: effects on growth, behaviour, adrenal and immune responses of finishing beef heifers. Anim Sci. 1997;64:53-62.

12. Fisher AD, Crowe MA, O'Kiely P, Enright WJ. Growth, behaviour, adrenal and immune responses of finishing beef heifers housed on slatted floors at 1.5, 2.0, 2.5 or $3.0 \mathrm{~m}^{2}$ space allowance. Livest Prod Sci. 1997;51:245-54.

13. Hickey MC, Earley B, Fisher AD. The effect of floor type and space allowance on welfare indicators of finishing steers. Irish J of Agri Food Res. 2003;42:89-100.

14. Lowe DE, Steen RWJ, Beattie VE, Moss BW. The effects of floor type systems on the performance, cleanliness, carcass composition and meat quality of housed finishing beef cattle. Livest Prod Sci. 2001;69:33-42.

15. Schlichting MC. Adaption of cattle to different floor types. In: Wierenga HK, Peterse DJ, editors. Cattle housing systems, lameness and behaviour. The Netherlands: Martinus Nijhoff; 1987. p. 87.

16. Schlichting MC, Smidt D. Welfare aspects of housing systems for veal calves and fattening bulls. CEC: Luxembourg; 1987.

17. Murphy PA, Hannan J, Monaghan M. A survey of lameness in beef cattle housed on slats and on straw. In: Wierenga HK, Peterse DJ, editors. Cattle housing systems, lameness and behaviour. The Netherlands: Martinus Nijhoff; 1987. p. 67.

18. Hickey MC, French P, Grant J. Out-wintering pads for finishing beef cattle: animal production and welfare. Anim Sci. 2002;75:447-58.

19. Owens D, McGee M, Boland T, O'Kiely P. Intake, rumen fermentation and nutrient flow to the omasum in beef cattle fed grass silage fortified with sucrose and/or supplemented with concentrate. Anim Feed Sci Technol. 2008;144:23-43.

20. Greenough PR, Vermunt JJ. Evaluation of subclinical lameness in a dairy herd and observations on associated nutritional and management factors. Vet Record. 1991;128:11-7.

21. Sprecher DJ, Hostetler DE, Kaneene JB. A lameness scoring system that uses posture and gait to predict dairy cattle reproductive performance. Theriogenol. 1997:47:1179-87.

22. Earley B, McDonnell B, O'Riordan E. Effect of floor type on the performance, physiological and behavioural responses of finishing beef steers. Acta Vet Scand. 2015;57:1-11. 
23. Scott GB, Kelly M. Cattle cleanliness in different housing systems. Farm Build Prog. 1989;1989(95):21-4.

24. Gupta S, Earley B, Nolan M, Formentin E, Crowe MA. Effect of repeated regrouping and relocation on behaviour of steers. Appl Anim Behav Sci. 2008;110(3):229-43.

25. EC. Council Regulation (EC) No 1183/2006 of 24 July 2006 concerning the community scale for the classification of carcasses of adult bovine animals. Off J Eur Union. 2006;L214:1-6.

26. Earley B, Crowe MA. Effects of ketoprofen alone or in combination with local anesthesia during the castration of bull calves on plasma cortisol, immunological, and inflammatory responses. J Anim Sci. 2002;80:1044-52.

27. Eckersall PD, Duthie S, Safi S, Moffatt D, Horadagoda NU, Doyle S, Parton R, Bennett D, Fitzpatrick JL. An automated biochemical assay for haptoglobin: prevention of interference from albumin. Comp Haem Int. 1999;9:117-24.

28. Becker U, Bartl K, Wahlefed AW. A functional photometric assay for plasma fibrinogen. Thromb Res. 1984;1984(35):475-84.

29. Rothel JS, Jones SL, Corner LA, Cox JC, Wood PR. A sandwich enzyme immunoassay for bovine interferon gamma and its use for the detection of tuberculosis in cattle. Aust Vet J. 1990;67:134-7.

30. Kirchner $\mathrm{M}$, Boxberger J. Loading of the claws and the consequences for the design of slatted floor. In: Wierenga HK, Peterse DJ, editors. Cattle housing systems, lameness and behaviour. The Netherlands: Martinus Nijhoff; 1987. p. 37.

31. Kaufmann W. Influence of the composition of the ration and the feeding frequency on $\mathrm{pH}$ regulation in the rumen and on feed intake in ruminants. Livest Prod Sci. 1976;3:103-14.

32. Keane MG, Drennan MJ, Moloney AP. Comparison of supplementary concentrate levels with grass silage, separate or total mixed ration feeding, and duration of finishing in beef steers. Livest Prod Sci. 2006;103:169-80.

33. Keane MG, Allen P. Effects of production system intensity on performance, carcass composition and meat quality of beef cattle. Livest Prod Sci. 1998;56:203-14.

34. Keane MG, Allen P. Effects of pasture fertiliser $\mathrm{N}$ level on herbage composition, animal performance and on carcass and meat quality traits. Livest Prod Sci. 1999;61:233-44.

35. Keane MG, Allen P. A comparison of Friesian-Holstein, Piemontese $\times$ Friesian-Holstein and Romagnola $\times$ Friesian-Holstein steers for beef production and carcass traits. Livest Prod Sci. 2002;78:143-58.

36. Caplis J, Keane MG, Moloney AP, O'Mara FP. Effects of supplementary concentrate level with grass silage, and separate or total mixed ration feeding, on performance and carcass traits of finishing steers. Irish J of Agric and Food Res. 2005:44:27-43.

37. Keane MG, Drennan MJ. A comparison of Friesian, Aberdeen Angus $\times$ Friesian and Belgian Blue $\times$ Friesian steers finished at pasture or indoors. Livest Sci. 2008;115:268-78.

38. Keane MG, Drennan M. Effects of supplementary concentrate level in winter, and subsequent finishing on pasture or indoors, on performance and carcass traits of Holstein-Friesian, Aberdeen Angus $\times$ Holstein-Friesian and Belgian Blue $\times$ Holstein-Friesian steers. Livest Sci. 2009;121:250-8.
39. Gygax L, Mayer C, Schulze Westerath H, Friedli K, Wechsler B. On-farm assessment of the lying behaviour of finishing bulls kept in housing systems with different floor qualities. Anim Wel. 2007;16:205-8.

40. Gygax L, Siegwart R, Wechsler B. Effects of space allowance on the behaviour and cleanliness of finishing bulls kept in pens with fully slatted rubber coated flooring. Appl Anim Behav Sci. 2007;107:1-12.

41. Andreae U, Smidt D. Behavioural alteration in young cattle on slatted floors. Hohenheimer Arbeiten. 1982;121:51-60.

42. Ruis-Heutinck LFM, Smits MCJ, Smits AC, Heeres JJ. Effects of floor type and floor area on behaviour and carpal joint lesions in beef bulls. In: Blokhuis HJ, Ekkel ED, Wechsler B, editors. Improving health and welfare in animal production, vol. 102. Wageningen: EAAP Publication; 2000. p. 29-36.

43. Andreae U. Zur Aktivita"tsfrequenz von Mastbullen bei Spaltenbodenhaltung. Landbauforschung Vo"lkenrode Sonderheft. 1979;48:89-94.

44. Irps H. Results of research projects into flooring preferences of cattle. In: Baxter SH, Baxter MR, MacCormack JAC, editors. Farm animal housing and welfare. The Netherlands: Martinus Nijhoff; 1983. p. 200.

45. Irps $\mathrm{H}$. The influence of the floor on the behaviour and lameness of beef bulls. In: Wierenga HK, Peterse DJ, editors. Cattle housing systems, lameness and behaviour. The Netherlands: Martinus Nijhoff; 1987. p. 73.

46. O'Connell J, Giller PS, Meaney WJ. Weanling training and cubicle usage as heifers. Appl Anim Behav Sci. 1993;37:185-95.

47. Phillips CJC, Morris ID. The locomotion of dairy cows on concrete floors that are dry, wet or covered with a slurry of excreta. J Dairy Sci. 2000;83:1767-72

48. Phillips CJC, Morris ID. The locomotion of dairy cows on floor surfaces with different frictional properties. J Dairy Sci. 2001;2001(84):623-8.

49. Phillips CJC, Morris ID. The ability of cattle to distinguish between, and their preference for, floors with different levels of friction, and their avoidance of floors contaminated with excreta. Anim Welf. 2002;11:21-9.

50. Phillips CJC, Morris ID, Lomas CA. A novel operant conditioning test to determine whether dairy cows dislike passageways that are dark or covered with slurry. Anim Welf. 2001;2001(10):65-72.

51. Webb NG, Nilsson C. Flooring and injury—an overview. In: Baxter SH, Baxter MR, MacCormack JAD, editors. Farm animal housing and welfare. The Hague: Martinus Nijhoff; 1983. p. 226-59.

52. Jerrams $\mathrm{S}$. Friction and adhesion in rigid surface indentation of nitrile rubber. J Mat Des. 2005;2005:251-8.

53. Jones ML, Allison RW. Evaluation of the ruminant complete blood cel count. Vet Clin N Am Food Anim Pract. 2007;2007(23):377-402.

54. Ishikawa H, Shirahata T, Hasegawa K. Interferon-g production of mitogen stimulated peripheral lymphocytes in perinatal cows. J Vet Med Sci. 1994;56:735-8.

55. Schalm OW. Balliere tindall and cox. Covent Garden: London; 1961. p. 130-1.

56. Schalm OW. Manual of bovine haematology: Anemia's/leukocytes/testing. Santa Barbara: Veterinary Practice Publishing; 1984.

57. Radostits OM, Gay CC, Blood DC, Hinchcliff KW. Veterinary medicine: a textbook of the diseases of cattle, sheep, pigs, goats and horses. 9th ed. London:W.B. Saunders; 2000.

\section{Submit your next manuscript to BioMed Central and we will help you at every step:}

- We accept pre-submission inquiries

- Our selector tool helps you to find the most relevant journal

- We provide round the clock customer support

- Convenient online submission

- Thorough peer review

- Inclusion in PubMed and all major indexing services

- Maximum visibility for your research

Submit your manuscript at www.biomedcentral.com/submit 